DOI: $10.17516 / 1997-1370-0837$

УДК $398+811.161 .1$

\title{
The Semantics of Participation in the Russian Language as a Reflection of the Cultural Universal «Own/Foreign» Concept and the «West/East» Opposition
}

\section{Igor Kim*}

Institute of Philology, Russian Academy of Sciences, Siberian Branch Novosibirsk, Russian Federation

Received 17.08.2021, received in revised form 22.08.2021, accepted 14.09.2021

\begin{abstract}
This paper deals with the issues of an important ethnic trait through the reflection in the Russian language and in the speech behavior of native speakers. This trait is focused around the need for actualization of «participation» or complicity in speech and social behavior as an invisible connection established in the inner world of the subject of the relationship of participation with other persons, animals, objects, spatial and social objects and even eras and ideas. The developed semantics of participation in the Russian language reflects the cultural universal concept of «own/foreign». L. Levy-Bruhl studied one member of that opposition theoretically and on the basis of extensive empirical material created the anthropological theory of participation. Russian linguists V.V. Ivanov, Yu. D. Apresyan, V.S. Khrakovsky and A. P. Volodin, I. I. Kovtunova studied concepts associated with the notion of participation in the mid-1980s using the material of Russian deixis and the category of possessiveness. In the Russian language, the semantics of participation is expressed by various linguistic means: the means of verbal and pronominal deixis, diminutives, possessive syntactic constructions and affixes, words with the semantics of emotional attitude and assistance.
\end{abstract}

Keywords: Own/Foreign, belonging, personal sphere of a person, diminutive, inclusive and exclusive, cultural universals, conceptual series.

This research is carried out within the framework of the project of the Institute of Philology of the Siberian Branch of the Russian Academy of Sciences «Cultural universals of verbal traditions of the peoples of Siberia and the Far East: folklore, literature, language» supported by a grant from the Government of the Russian Federation for the promotion of research conducted under the guidance of leading scientists, contract No. 075-15-2019-1884.

Research area: linguistics.

(C) Siberian Federal University. All rights reserved

* Corresponding author E-mail address: kimkim27601@yandex.ru 
Citation: Kim, I. (2021). The semantics of participation in the Russian language as a reflection of the cultural universal «Own/Foreign» concept and the «West/East» opposition. J. Sib. Fed. Univ. Humanit. soc. sci., 14(10), 1538-1546. DOI: 10.17516/1997-1370-0837

\title{
Семантика сопричастности в русском языке как отражение культурной универсалии «свое / чужое» и оппозиция «Запад / Восток»
}

\author{
И. Ким \\ Институт филологии СО РАН \\ Российская Федерация, Новосибирск
}

\begin{abstract}
Аннотация. Данная статья посвящена особенностям отражения в русском языке и в речевом поведении носителей русского языка важной этнической черты необходимости актуализации в речи и социальном поведении сопричастности, под которой понимается незримая связь, устанавливаемая во внутреннем мире субъекта отношения сопричастности с другими лицами, животными, предметами, пространственными и социальными объектами, даже эпохами и идеями. Развитая семантика сопричастности в русском языке отражает культурную универсалию «свое / чужое», один из членов которой теоретически и на обширном эмпирическом материале изучен в культурно-антропологической теории партиципации Л. ЛевиБрюля. Независимо друг от друга понятия, связанные с сопричастностью, в середине 80-х гг. XX в. рассмотрены на материале русского дейксиса и категории посессивности виднейшими российскими лингвистами - Вяч. Вс. Ивановым, Ю. Д. Апресяном, В.С. Храковским и А.П. Володиным, И.И. Ковтуновой и др. Интерес к «лингвистике сопричастности» был остановлен политическими и социальными процессами конца 80-90-х гг., в результате чего ценность отношений человеческой близости была отодвинута в пользу индивидуализма. В русском языке чрезвычайно развита семантика сопричастности, которая выражается разнообразными языковыми средствами: средствами глагольного и местоименного дейксиса, диминутивами и другими средствами выражения оценки, посессивными синтаксическими конструкциями и аффиксами, лексикой со значением эмоционального отношения и содействия.
\end{abstract}

Ключевые слова: свое-чужое, сопричастность, личная сфера человека, диминутив, инклюзив и эксклюзив, культурные универсалии, понятийный ряд.

Исследование выполнено в рамках проекта Института филологии СО РАН «Культурные универсалии вербальных традиций народов Сибири и Дальнего Востока: фольклор, литература, язык» по гранту Правительства РФ для государственной поддержки научных исследований, проводимых под руководством ведущих ученых (соглашение № 075-15-2019-1884).

Научная специальность:10.02.00 - языкознание. 
There is an important ethnic trait reflected in the Russian language, both in verbal and nonverbal behavior of native speakers. Specialists in ethnopsychology and linguistics have observed this trait many times and describe it as the need to mark a certain type of relationship between the author of the statement and the other subject or topic in the act of speech. I.I. Kovtunova calls this relationship as closeness, Yu. D. Apresyan believes that by doing so, the Russian person includes his communicative partner into his personal sphere. However, 'complicity' as suggested by V. S. Khrakovsky and A.P. Volodin would be a more appropriate term. Complicity is the «invisible», internal relationship that connects the speaker and the other items or topics with a varying level of sustainability, however the speaker is definitely aware of it and it has a verbal or other kind of manifestation that allows the external observer to define or assume its presence with a reliable level of certainty. For instance, in Russian everyday life, collaborative eating or even more so alcohol consumption is a mark of complicity.

It seems that the notion of complicity represents an important cultural universal «own/ foreign» rule, however, its representation in the Russian language and in Russian social behavior is vividly idioethnic, manifesting the Russian mentality in a culture-ethnic opposition of «West - East».

In the first quarter of the 20th century, Charles Bally formulated an important cultural opposition of analytism and impressionism that characterizes horizontal distribution of leading national cultures of Europe, connected with four countries: United Kingdom, France, Germany and Russia (Bally, 2003). Analytism can be represented as perception of the world in a «deconstructed way», with accentuated and structural components. Impressionism is understood as a way of describing the world and its fragments as a whole. According to Bally, the level of analytism decreases as we move from West to East, while the level of impressionism increases (see Fig. 1). Impressionism and analytism, in Bally's opinion, spread across all layers of national culture, from basic (language, body and domestic behavior) to the «highest» (art, science, philosophy and religion).

In terms of cultural anthropology and ethnic psychology, there are more differentiated oppositions including the notion of perceptual (cognitive) style by H.A. Witkin (Cole, Scribner, 1977: 104). It is worthwhile to note that perceptual style connects two important contradistinctions that do not necessarily consistently correlate. H. Witkin believed that articulated style is often connected with egocentricity and globalism correlates with the value of society. Theoretically, however, other interrelations of these paired notions are possible, such as globalism with individualism or articulatedness with the idea of society dominating over the individual.

In relation to the opposing «West/East» views, a remarkable feature of Russian national culture is its borderline nature. Russia is situated on the border between the eastern and the western worlds. We can say that the tendency towards holistic perception of the world's phenomena and domination of society over an individual increases further, the more east one travels from the European part of Russia. Thus, concerning the «analytism/impressionism (articulatedness/globality)» opposites we can speak about a wider «West/East» contrapo-

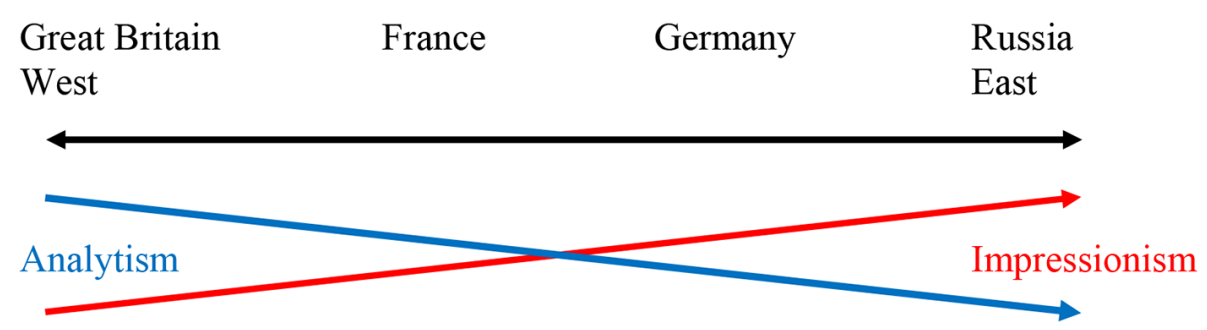

Fig. 1. Geographic distribution of analytism and impressionism 
sition compared to the European and furthermore, it includes all the significant cultures of Eurasia.

Russia's borderline nature is manifested in the notion of «Eurasianism» that served as an alternative ideologem to communism at a certain stage of the country's existence; an ideology of the social democratic worker's party that won. Interestingly, famous linguist and phonologist N. S. Trubetskoy was the ideologist of Eurasianism. He actively rejected European values and considered Romano-Germanic states to be their source, mainly United Kingdom and France. From Trubetskoy's point of view, Romano-Germanic countries can be characterized as egocentric and chauvinistic (Trubetskoy, 1995: 55-104). Roman-Germanic culture is opposed by the Eurasian one, that can be in turn characterized with such an important trait as «symphonicity», manifested in the wholeness of the nation (Trubetskoy, 1995: 105). Trubetskoy considered the Russian nation to be the basic carrier and exponent of Eurasian culture.

Symphonicity of Russian culture in Trubetskoy's understanding is connected with the cultural universal «own/foreign» rule that can be seen as a notion-value opposition. It stems from societal psychology and the basic principles of human world perception.

Primarily it concerns the member of the «own» opposition that correlates with the notion of participation by Lévy-Bruhl.

L. Lévy-Bruhl, a French anthropologist from the first half of the 20th century, developed an original and universal anthropological theory that explains specific aspects of the world-perception and social behavior in traditional cultures that used to be called primitive.

In his polemic with the representatives of the British anthropological school that dominated in the beginning of the 20th century, L. Lévy-Bruhl based on the views of E. Durkheim and his understanding of the collective representations (Verstin, 2013: 206), formulated important points of his theory:

1. Beliefs and customs of traditional cultures are based on representations of the collective conscious rather than individual conscious (Lévy-Bruhl, 1994).
2. Primal mentality resides on the principal unsimilar to the principle of differentiation (contradiction), which forms a civilized culture. Difference and contradiction are the base of analytism in modern culture. Primal mentality is based on the principle of participation rather than contradiction (Lévy-Bruhl, 1994: 87-88), that has a more «impressionist» nature. Collective representations of the primitive man «instead of logical relations (inclusions and exclusions) imply more or less clearly defined, usually vividly experienced participations (communions)» (Lévy-Bruhl, 1994: 65).

The participation principal is connected with the fact that a human in traditional culture is not entirely an individual, meaning he is not entirely disconnected from nature and community. This unfinished separation is provided by participations, special mystical connections of the human with members of his ancestry, totemic animals or plants, place of living, its flora and fauna. These connections are invisible but real for a member of the traditional culture.

It seems that a person of traditional culture is not completely isolated from the environment, still being connected to it by invisible ties of participation. However, the elements of the environment, not only people, but also other realia of the surrounding world, in turn, are a continuation of the human: «The idea of the soul is absent in primitive people. It is replaced by the idea, generally a very emotional one, about one or several participations that coexist and cross (over) but do not yet merge into the clear consciousness of a truly single individuality. A member of a tribe, totem, clan feels his mystical unity with his social group, his mystical unity with an animal or plant species, that is his totem, with the soul of dreams, his mystical unity with the forest soul, etc.» (ibid, p. 73). Participations connect not only a person with the world around him, but also other elements of the world with each other.

According to L. Lévy-Bruhl, in order to establish or actualize the connection of participation, a traditional person performs magical actions. In order to not destroy this connection, he limits his behavior with the help of taboos. Violations of taboos lead to the destruction of 
participation as well as undesirable or even catastrophic consequences.

L. Lévy-Bruhl's theory of participation was received with an active rejection in the anthropological community, primarily in its British part, which consisted of criticism from the standpoint of animism adopted in British anthropology (see, for example, (de Laguna, 1940)). In addition to the ideological rejection of theoretical attitudes of Lévy-Bruhl, the critics' argumentation concerned the empirical basis of his research. Eventually, a generational change took place in French anthropology, highlighting the structuralism of K. Levy-Strauss with his theory of myth, based on the metaphor of «bricolage», according to which mythological consciousness instead of constructing a concept for new reality uses a ready-made concept, at least somewhat applicable to reflect the needed essence, just as a player in «bricolage», to perform the required function, adapts the mechanism at hand with a completely different purpose (Levi-Strauss, 1994: 126-133).

L. Lévy-Bruhl's theory of participation did not receive further development, although, for instance, K. G. Jung recognized the presence of a system of participations in human thinking (Jung, 1997: 19; Jung, 1998).

Modern anthropology stems from the fact that a «civilized» person has a «layered», multilevel structure of consciousness, and the principle of participation, described by L. LévyBruhl in relation to traditional cultures, operates at the ordinary, lower level (compare F. Bartlett's views on these phenomena (Cole, Scribner, 1977: 33-34)).

Participation, possessing a universal nature, forms an opposition with alienation, forming the value sequence «own/foreign». By limiting the circle of persons, animals and plants involved, a man of traditional culture limits «his» space, much like a modern civilized man, who separates his own world from the world around him, marking some of it as foreign. This foreign part is not only distanced from him, but also clearly rejected.

It is important to find out whether the Russian concept of complicity is the same notion as Lévy-Brul's participation concept. To prove this, it must be shown that participation is an important part of the non-verbal and verbal behavior of a Russian person where the Russian language and Russian culture contain a series of means that can be interpreted as means of actualizing participation.

The notion of complicity is extremely productive for describing the Russian mentality and the Russian «naive» (Yu.D. Apresyan's term) picture of the world. Participation is incorporated in the everyday existence of a Russian person; it forms the patterns and unwritten rules of their life, which in many respects contradict the written laws and norms.

Numerous facts of the presence and actualization of participation have been revealed in Russian culture, especially in everyday and ritual behavior, as well as in the Russian language, its grammar and vocabulary.

Participation is manifested and actualized in behavior and everyday rituals:

1. Spatial relationships are studied from a semiotic point of view by proxemics - «the science that studies the spatial parameters of human behavior» (Galichev, 1987: 8). The main proxemic regularities are based on the allocation of conditional spatial boundaries where a person is placed as a reference point. Each of the boundaries marks the area within which he can allow another person with whom he has some sort of relations of complicity with: an intimate zone (distance), a personal zone, a social zone, a public zone (Galichev, 1987: 12-13; Pease, 1992: 35-36). It is interesting to observe the intersection of terms: Yu. D. Apresyan and V. V. Ivanov use the term «personal sphere» in their works with a vivid spatial metaphor. From a proxemic point of view, the current widely popular term «social distancing» is extremely interesting, which must be observed in crowded places and is nominally equal to $1.5 \mathrm{~m}$, which corresponds to the division, for example, of A. Pisa into communicative zones, however in reality it is significantly less than these $1.5 \mathrm{~m}$ and usually does not exceed this distance.

2. Gestures, postures and facial expressions are studied by kinesics - the semiotics of bodily movements (Galichev, 1987; Kreidlin, 2001; Molchanova, 2014: 18). A relaxed and open posture, turning and movement of the 
body towards another person, opening gestures, relaxed facial expressions, a smile - all serve as signals of participation, while closing gestures, on the contrary, are associated with a break in complicity.

3. Positive touch as a manifestation of complicity through bodily contact is considered by takesics, or haptics, a semiotic discipline that studies touch (Molchanova, 2014: 15). A friendly pat on the shoulder or back, touching an arm or shoulder while talking, hugging and kissing $^{1}$ are clear signs of complicity.

4. A person who has a sense of complicity with another person can allow them to interact with their belongings. Similarly, a sense of complicity with another person gives the right, sometimes falsely so, to interact with the belongings without express permission. Handling the belongings of a person involved is often combined with another way of actualizing complicity - the liberty to enter their personal territory. Here is an example from Y. Trifonov, which describes both the moving of things and the entry into personal territory as a mutual manifestation of complicity: The following day, Nyura suddenly appeared. <..> She felt very sorry for Rita: 'Oh, Margarita Nikolaevna, how are you getting by without any help?' Rita would reply that it was very difficult. 'Of course,' said Nyura. 'You need someone here.' And the fact that she mentioned this «someone» who would take her place so calmly and indifferently meant that she had accepted it all and there was no need to talk about anything. <...> After lunch, Nyura washed the dishes, and then Rita asked her to take out the trash (Yu. Trifonov. Preliminary results).

5. Collaborative eating and alcohol consumption is also one of the means of actualization or a way of establishing complicity. Reception of guests, a friendly party, corporate event is all means of maintaining personal relationships. Performers, drivers, other people serving a festive event, according to custom, should receive food and/or drink «from the table». Large-scale and/or prolonged joint activities involve a final «banquet». Hiring, firing,

\footnotetext{
It is worth noting that a touch is a very intense intrusion in a person's private space and it is thus risky for it can lead to a negative reaction from the communicative partner.
}

anniversaries, or funerals also involve eating together.

6. Joint actions and assistance to a close person or a mere acquaintance are also actualizers of complicity, and it is important to note that they can be performed contrary to the requirements of the law. One of the forms of corruption - nepotism (kumovstvo) - takes its name from the relationship of spiritual kinship: kumovia are a couple in which one person is the godfather or godmother for the other's child. For example, «godfather», a euphemism for the head of a mafia clan from the novel by M. Puzo «Godfather» and the film trilogy with the same title by F. F. Coppola. In fact, the mafia structure of society in some states exists as a parallel system of social relations, based not on the law, but on the ties of complicity.

7. The complicity of communicants is one of the important conditions for the success of communication. Establishment of complicity is achieved, in addition to linguistic means, by a wide range of non-verbal means, such as gestures, facial expressions, posture, touching, phonation means, in particular the use of timbre, raising and lowering the main tone, intonation, and others. For example: 'In the recent past an athlete, and now what do you do, Denis Ivanovich?' asked the journalist. Denis Ivanovich did not accept the friendly tone (N. Leonov. Trap).

There are also numerous linguistic means associated with the actualization of ownership, such as:

1. The most understandable lexical means of expressing complicity are verbs, adjectives directly denoting complicity, as well as their derivatives. These include the adjectives dear (with the semantic component of a family connection in Russian), close, etc., as well as their derivatives, the verbs to love, trust, sympathize, respect, befriend, etc., as well as their derivatives, see, for example: When you come to the Kremlin, go to the ancient walls, feel their closeness, feel the blood connection with them (Trud, 11.08.1987. - National corpus of the Russian language).

2. Words and grammatical tools for possessiveness in direct and indirect meanings are used to indicate ownership. While describing 
the range of phenomena that fall into the personal sphere of the Indo-European proto-language speaker, V. V. Ivanov used the means of expressing inalienable belonging in the Hittite language (Ivanov, 1989: 11-14): 1) the terms of kinship, 2) names of body parts, 3) designation of a person's private space, 4 ) designations of a person's private property, 5) words denoting the duties and responsibilities of a person, 6) designation of hazardous conditions and properties, as well as actions preventing them, 7) designations of atmospheric phenomena, but only for God. Possessiveness, based on somatic semantics and belonging/possession semantics, often expresses relations that cannot be reduced to this type of semantics. Complicity may well be the semantic prototype for this wide range of relationships. Relational nouns with the meaning of a person are adjacent to the means of expressing possessiveness, such as the terms of kinship, properties and spiritual kinship (father, sister, matchmaker, godfather, etc.), territorial congruence (compatriot, fellow countryman, neighbor, etc.), emotional and social closeness (friend, comrade, girlfriend, classmate, etc.) (Arutyunova, 1980). Those relational nouns have the semantic valence of possessor to the possessive adjective or genitive form of a noun. Relational nouns are often used figuratively to denote participation that is not based on objective relationships of kinship, property or intimacy of another kind, for example: 'I have a very bad rope on the sled, you tie a new one.'. 'I got one. I'll surely do. And you, brother, give me a promise: don't cry anymore, okay? It's no good for you, and mom gets upset, and it's just not a manly thing to do. I don't like it ... Promise you won't cry.' (V.F. Panova. Seryozha (1955). - National corpus of the Russian language). The boy Seryozha and Korostelev talking to him are not related and belong to different generations. Korostelev used the allocution brother to actualize complicity.

3. Deictic pronouns and personal verb forms. Yu. D. Apresyan (1986) shows the distinction between $V y$ (you formal) and ty (you informal) and the corresponding forms of the verb, in addition to the social function of denoting official/unofficial communication and/ or relative social hierarchy, performing the function of including/withdrawing from the speaker's personal sphere. I. I. Kovtunova (1986) demonstrated how translation into the second person, into the position of a lyrical addressee, «brings» the character of a poetic text closer to the author, compare, for example: Oh Volga!.. my cradle! Has anyone loved you (informal) as I do? (N. A. Nekrasov. On the Volga).

The term pseudo-inclusive, introduced by Yu.D. Apresyan for the use of the first-person plural pronoun to designate a single addressee of speech (Apresyan, 1986), has been widely used in linguistics. There are several options for pseudo-inclusive and pseudo-exclusive. These are we: doctoral (Well, how do we feel?), camera man's (Let's look at the presenter!), policeman's (Are we violating?), bus conductor's (Let's not block the doors!), pseudo-exclusive maternal (We are already teething!), etc.

4. The means of expressing evaluation make it possible to actualize the participation with the assessed reality and/or the addressee of the speech. At the same time, actualization is achieved with the very fact of using a value judgment, involving the person being assessed into the speaker's system of values; however, diminutives as an expressive evaluative means directly involving the designated reality or the addressee into the speaker's «personal sphere» (Spiridonova, 1997; see also Vezhbitskaya, 1997). For example, the use of diminutives in the speech of drivers and conductors of municipal buses in Krasnoyarsk (Kiseleva, 1997: 12): Let's not release the doors (dim.), (People standing in the) middle (dim.) / let's go forward now, If we want to get off, let's press the button (dim.) in advance. A large number of diminutives are used in the formation of "household names», for example: Tatiana / Tania / Tan-echk-a / Tan-iush-a / Tan-ius-echk-a / $N$-ius-ia / N-iush-a, etc. (Vezhbitskaya, 1997: 89-200).

5. Words and utterances with the meaning of certain social actions that include the idea of belonging. So, for example, the verbs help, assist, contribute, Griboyedov's poradet' (to take care of someone and assist in some way), expressing assistance, have a presupposition of complicity, for example: And the only person who can help her now is Lyova, who has no 
idea how she, Natasha, feels about him. (N. Leonov. Repentance). In this case, there is a special register of narrative discourse - improperly direct speech, or free indirect discourse. The peculiarity of this proposal is that it reflects the point of view not of the author, but of the character Natasha, who asks another character, Lev Gurov, to help her in an important matter. Help is a manifestation of complicity. Therefore, in order to evoke a sense of belonging in the character, Natasha tries to show her own sense of belonging (Lyova, who has no idea how she, Natasha, feels about him.).

Immersed in verbal communication, linguistic means of actualizing complicity form ensembles with each other, as well as with non-verbal means. Consider the interaction of linguistic means in this short statement: Poydem-ka my s toboy, druzhishche, vrezhem pivka: 'Let's go (post-positive particle) you and me, buddy (aug.), let's grab some beers (dim.)' (Oleg Divov. Vybrakovka (1999). - National corpus of the Russian language). Despite the short nature of the statement, it uses a whole series of means of actualizing complicity:

1) a relational noun druzh-ishch-e 'buddy' is used as an address, denoting emotional closeness to the speaker; at the same time, an augmentative was used for the word druzh-ishch-e 'buddy', in this case it expresses not pejorativeness, but, on the contrary, hypochoricity;

2) the form of an inclusive Poydem-ka (druzhishche,) vrezhem: 'Let's go, let's grab' is used, denoting joint activities;
3) a post-positive particle is used $(-k a)$, denoting a decrease in categoricality, which is typical for an unofficial communicative situation;

4) the speaker offers the listener a proposal for a joint drink of alcohol, which is a nonverbal means of actualizing complicity;

5) the speaker addresses the listener in the informal 'ty' (you informal), which is a means of actualizing complicity;

6) the form of the «gastronomic» diminutive of beer piv-k-a is used, which actualizes complicity;

7) the speaker uses the colloquial verb vrezat': 'to grab' to indicate drinking, which is an expressive designation of an action. This is evidence of an unofficial communicative situation.

In Russian speech, especially in casual personal communication, it is possible to use concentrated means of actualizing complicity, creating a special atmosphere of friendly communication.

The density of the use of verbal and non-verbal means of actualizing complicity in Russian unofficial communication suggests that the attitude of complicity in Russian society is an important factor in communication and social life. The $u$-chast'-i-e 'complicity' is the loan translation of the Latin participatio, -onis with the same root -part- / -chast'-. This, in turn, suggests that the cultural universal «own/foreign» rule plays a significant role in the life of the Russian people.

\section{References}

Apresian, Iu.D. (1986). Deiksis v leksike i grammatike i naivnaia model' mira [Deixis in vocabulary and grammar and the naive model of the world], In Semiotika i informatika [Semiotics and informatics], $28,5-33$.

Arutiunova, N.D. (1980). K probleme funktsional'nykh tipov leksicheskogo znacheniia [On the problem of functional types of lexical meaning], In Aspekty semanticheskikh issledovanii [Aspects of semantic research], Moscow, Nauka, 156-249.

Bally, Ch. (2003). Impressionizm i grammatika [Impressionism and grammar], In Bally, Ch. IAzyk i zhizn' [Language and life]. Moscow, Editorial URSS, 186-199.

Cole, M., Scribner, S. (1977). Kul'tura i myshleniie: Psikhologicheskii ocherk [Culture and Thinking: A Psychological Essay], Moscow, Progress. 261 p.

Galichev, A.I. (1987). Kinesicheskii i proksemicheskii komponenty rechevogo obshcheniia [Kinesic and proxemic components of speech communication], Author's abstract. Moscow. $22 \mathrm{p}$. 
Jung, K.G. (1997) K voprosu o podsoznanii [To the subject of the subconscious]. In Jung, K.G, von Franz, M.-L., Henderson, J.L. et al. Chelovek i iego simvoly [Man and his symbols]. Moscow, Serebrianyie niti, 13-102.

Jung, K.G. (1998). Tevistokskiie lektsii: Issledovaniie protsessa individuatsii [The Tavistock Lectures: A Study of the Individuation Process]. Moscow - Kiev. 295 p.

Kiseleva, L.A. (1997). Obshcheniie v gorodskom transporte. Opyt filologicheskogo opisaniia (na materiale Krasnoiarska) [Communication in public transport. The experience of philological description (based on the material of Krasnoiarsk)]: Author's abstract / Novgorod State Univ. Novgorod. 21 p.

Kovtunova, I.I. (1986). Poeticheskii sintaksis [Poetic syntax], Moscow, Nauka. 206 p.

Kreidlin, G.E. (2001). Kinesika [Kinesics], In Grigorieva, S.A., Grigoriev, N.V., Kreidlin, G. E. Slovar' iazyka russkikh zhestov [Dictionary of Russian Sign Language]. Moscow - Vienna, Languages of Russian Culture; Vienna Slavic Almanac, 166-254.

Laguna, F. de. (1940). Levy-Bruhl's Contributions to the Study of Primitive Mentality, In The Philosophical Review. 49(5), 552-566.

Levi-Strauss, C. (1994). Pervobytnoie myshlenie [Primitive thinking]. Moscow: Respublika. 384 p.

Levy-Bruhl, L. (1994). Sverkh»estestvennoie v pervobytnom myshlenii [Supernatural in primitive thinking]. Moscow, Pedagogika-Press. 608 p.

Molchanova, G.G. (2014). Kognitivnaia neverbalika kak polikodovoie sredstvo mezhkul'turnoi kommunikatsii: kinesika [Cognitive non-verbal as a polycode means of intercultural communication: kinesics], In Vestnik Moskovskogo universiteta. Seriia 19. Lingvistika i mezhkul'turnaia kommunikatsiia [Moscow University Bulletin. Series 19. Linguistics and Intercultural Communication], 2, 13-30.

Pease, A. (1992). IAzyk telodvizhenii: Kak chitat' mysli drugikh po ikh zhestam [Body language: How to read the thoughts of others by their gestures]. Moscow, IQ. 262 p.

Spiridonova, N.F. (1997). Russkie diminutivy: problemy obrazovaniia i znacheniia [Russian diminutives: problems of derivatiom and meaning], In Tr. Mezhdunar. seminara «Dialog'97 po komp'iuternoi lingvistike i ee prilozheniiam» [Tr. Int. seminar «Dialogue'97 on computational linguistics and its applications»] Iasnaia Poliana, 10-15.06.1997. Moscow, 264-265.

Trubetskoi, N.S. (1995). Istoriia. Kul'tura. Iazyk. [History. Culture. Language], Moscow, Publishing group «Progress», $800 \mathrm{p}$.

Verstin, I.S. (2013). Problema pervobytnogo myshleniia v kontseptsii L. Levi-Briulia [The problem of primitive thinking in the concept of L. Lévy-Bruhl], In Vestik Universiteta [University Bulletin], 11, 205-212.

Vezhbitskaia, A. (2001). Sopostavlenie kul'tur cherez posredstvo leksiki i pragmatiki [Comparison of cultures through vocabulary and pragmatics]. Moscow, Iazyki Slav'anskoi Kul'tury, $272 \mathrm{p}$. 